\title{
Chemical conversion of a solid body of the composite gypsum/ polyhydroxybutyrate in hydroxyapatite/polyhydroxybutyrate
}

\section{(Conversão química de um corpo sólido do compósito gesso/poli- hidroxibutirato em hidroxiapatita/poli-hidroxibutirato)}

\author{
A. A. Barbosa ${ }^{1,2 *}$, S. A. Júnior ${ }^{2}$, A. C. S. Dantas ${ }^{1}$, A. V. Ferraz ${ }^{1}$ \\ ${ }^{1} F e d e r a l$ University of Vale do São Francisco, Av. Antonio Carlos Magalhaes 510, Juazeiro, BA, Brazil \\ ${ }^{2}$ Federal University of Pernambuco, Av. Jorn. Anibal Fernandes, s/n, Recife, PE, Brazil
}

\begin{abstract}
The transformation of the gypsum into hydroxyapatite allows added value to this raw material, because the ceramic obtained has a high commercial value in relation to gypsum, while the polymer adds biocompatibility and bioactivity properties to the biocomposite. Thus, hydroxyapatite/polyhydroxybutyrate composites were prepared from the gypsum/polyhydroxybutyrate, using a $10 \%$ mass ratio of the polymer. The material was obtained by means of a chemical conversion carried out in a solution of ammonium hydrogen phosphate $\left(0.5 \mathrm{~mol} . \mathrm{L}^{-1}\right)$ and alkaline medium (ammonium hydroxide $6.0 \mathrm{~mol} . \mathrm{L}^{-1}$ ) for $\mathrm{pH}$ control. The reaction occurred at $100{ }^{\circ} \mathrm{C}$ at different test times. Analyzes of infrared spectroscopy showed functional groups characteristic of hydroxyapatite after $36 \mathrm{~h}$ of reaction; in addition, the biomaterial was identified as the major phase in X-ray diffraction patterns. Scanning electron microscopy of the materials before and after conversion showed a clear change in their morphologies, indicating the success of the synthesis.
\end{abstract}

Keywords: gypsum, composite, hydroxyapatite, polyhydroxybutyrate.

\section{Resumo}

A transformação do gesso em hidroxiapatita permite agregar valor a essa matéria-prima, pois a cerâmica obtida possui alto valor comercial em relação ao gesso, enquanto o polímero acrescenta propriedades de biocompatibilidade e bioatividade ao biocompósito. Assim, compósitos de hidroxiapatita/poli-hidroxibutirato foram preparados a partir do gesso/poli-hidroxibutirato, usando uma proporção em massa de $10 \%$ do polímero. O material foi obtido por meio de uma conversão química realizada em solução de hidrogenofosfato de amônio $\left(0,5 \mathrm{~mol} . \mathrm{L}^{-1}\right)$ e meio alcalino (hidróxido de amônio 6,0 mol.L $\left.{ }^{-1}\right)$ para controle de pH. A reação ocorreu a $100{ }^{\circ} \mathrm{C}$ em diferentes tempos de teste. Análises de espectroscopia no infravermelho mostraram grupos funcionais característicos de hidroxiapatita após 36 h de reação; além disso, o biomaterial foi identificado como a fase majoritária em difratogramas de raios X. Microscopia eletrônica de varredura dos materiais antes e após a conversão mostrou uma clara mudança em suas morfologias, indicando o sucesso da síntese.

Palavras-chave: gesso, compósito, hidroxiapatita, poli-hidroxibutirato.

\section{INTRODUCTION}

Hemihydrate gypsum $\left(\mathrm{CaSO}_{4} \cdot 0.5 \mathrm{H}_{2} \mathrm{O}\right)$, which is abundantly produced in the region of Araripe in the State of Pernambuco-Brazil, is obtained by calcination of dihydrate gypsum $\left(\mathrm{CaSO}_{4} \cdot 2 \mathrm{H}_{2} \mathrm{O}\right)$. The mineral found at the mentioned site presents a high degree of purity, ranging from $80 \%$ to $95 \%$. In spite of this, it finds its main use in the construction industry as a high-quality material of low cost [1-3]. One of the alternatives to add value to gypsum lies in its processing, that is to say, the improvement of its properties [1], or else its chemical conversion into a different material, which in the present case is hydroxyapatite $\left[\mathrm{Ca}_{10}\left(\mathrm{PO}_{4}\right)_{6}(\mathrm{OH})_{2}\right]$. The latter is a biomaterial with chemical and crystallographic

*amanda.barbosa@univasf.edu.br

(D) https://orcid.org/0000-0003-0266-4604 similarity to the human bone matrix [4]. The transformation of gypsum into hydroxyapatite allows a great addition of value to the raw material, as the obtained ceramic has an elevated commercial value in comparison to gypsum. The cost of $5.0 \mathrm{~g}$ of hydroxyapatite at $99.9 \%$ purity is $\mathrm{R} \$ 125.12$ [5], whereas a $40 \mathrm{~kg}$ bag of gypsum- $\beta$ costs on average $\mathrm{R} \$ 20.00$.

Gypsum is a material that is highly moldable when in paste form, allowing solid bodies of previously defined shapes to be obtained [6]. Hydroxyapatite, on the other hand, is difficult to be molded in complex shapes due to its high fragility, which is directly related to the elevated crystallinity of the material $[7,8]$. Bearing this in mind, our present aim is the formation of composites with hydroxyapatite (HA) and biodegradable and bioactive polymers, such as PHB (polyhydroxybutyrate), which is a thermoplastic material of the class of polyhydroxyalkanoates, chemically being polyesters with molecular formula $\mathrm{C}_{4} \mathrm{H}_{6} \mathrm{O}_{2}$. This polymer, 
besides being biocompatible, offers an advantage as it decomposes gradually while maintaining its mechanical properties for a longer time [9]. In addition, it is possible to verify in the literature that, for example, the union of the hydroxyapatite with the PHB polymer results in the increase of the bioactivity of the composite, being this a characteristic of great importance for the biomaterials [10]. The chemical conversion of the G/PHB (gypsum/ polyhydroxybutyrate) composite into the HA/PHB (hydroxyapatite/polyhydroxybutyrate) composite seeks the union of various factors that complement each other in order to obtain a material with improved properties, making good use of an abundant and highly pure raw material.

\section{MATERIALS AND METHODS}

Production of the block: the gypsum used to obtain the G/PHB composite was supplied by Gesso Mineral Ind., a company belonging to the gypsum pole of Araripe, Pernambuco State-Brazil, whereas the PHB was supplied by PHB Ind., Serrana, São Paulo State-Brazil. The G/PHB cylindrical blocks (dimensions $11 \times 22 \mathrm{~mm}$ ) were prepared by molding the paste that had been prepared according to the NBR 12128 [11]. The composite was obtained from the mixture of the powders (gypsum and polyhydroxybutyrate) in the proportion of $10 \mathrm{wt} \%$ of the polymer, which was then powdered on the surface of the water, at a water/ gypsum ratio of 0.7 . The gypsum, polymer and the composite were characterized using X-ray diffraction (XRD, Siemens, Diffract ACT 1000, CuK $\alpha$ radiation), with phase identification using the X'pert HighScore Plus software (v. 2.0a), scanning electron microscopy (SEM, Hitachi, TM-1000) and Fourier-transform infrared (FTIR) spectroscopy (Bruker, I FS66).

Conversion of the composite into hydroxyapatite: the conversion of the G/PHB into HA/PHB composite was accomplished in a solution of ammonium hydrogen phosphate $0.5 \mathrm{~mol} . \mathrm{L}^{-1}$ and ammonium hydroxide $6.0 \mathrm{~mol} . \mathrm{L}^{-1}$, using values calculated for the synthesis of hydroxyapatite with $\mathrm{Ca} / \mathrm{P}$ ratio of 1.66 . G/PHB composite blocks were submerged in $200 \mathrm{~mL}$ solution of $\left(\mathrm{NH}_{4}\right)_{2} \mathrm{HPO}_{4} 0.5 \mathrm{~mol} . \mathrm{L}^{-1}$ contained in a three-neck flask at $100{ }^{\circ} \mathrm{C}$ for different reaction times $(8,16,24$ and $36 \mathrm{~h})$. The $\mathrm{pH}$ of the medium was controlled by adding $\mathrm{NH}_{4} \mathrm{OH} 6.0 \mathrm{~mol} . \mathrm{L}^{-1}$. At the end of the reaction time, the blocks were washed in deionized water until reaching neutral $\mathrm{pH}$ and then placed in an oven at 50 ${ }^{\circ} \mathrm{C}$ for approximately $2 \mathrm{~h}$. The HA/PHB composites were initially characterized by analyzing their morphology on the fractured surface using an SEM, while the chemical elements present in the sample were verified by energy dispersive spectroscopy (EDS) coupled to the SEM. The FTIR analyzed the samples that had been prepared as $\mathrm{KBr}$ pellets pressed under vacuum, obtaining the absorption bands related to the present compounds. The $\mathrm{X}$-ray diffractometer recorded XRD patterns in steps of $0.02^{\circ}$ at $2 \theta$ and integration time of $1 \mathrm{~s} / \mathrm{step}$, showing the different crystalline phases of the obtained material.

\section{RESULTS AND DISCUSSION}

Characterization of G/PHB composite: in the analysis of the G/PHB composite (Fig. 1), sharp and well-defined crystals that characterize the dihydrate gypsum were verified in the SEM micrographs, as well as a good homogeneity of the material. Furthermore, the EDS analysis of the composite confirmed the presence of chemical elements that formed the precursor materials, verifying the presence of carbon belonging to the polymer, and also of calcium and sulfur characteristic of gypsum.

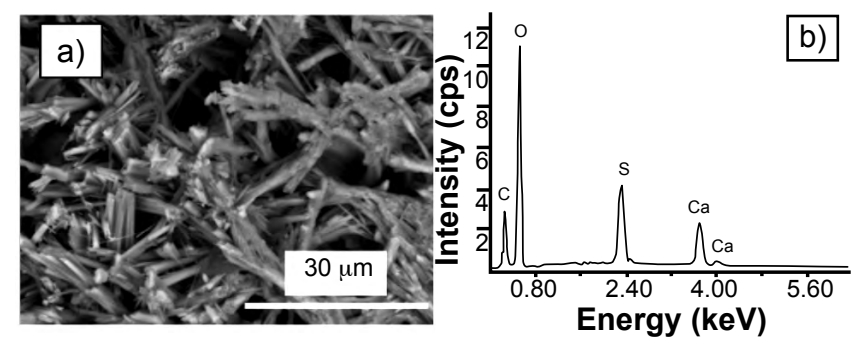

Figure 1: SEM micrograph (a) and EDS spectrum (b) of G/PHB composite.

[Figura 1: Micrografia de MEV (a) e espectro de EDS (b) do compósito G/PHB.]

Fig. 2a shows the infrared spectrum of the G/PHB composite, showing the absorption bands that are characteristic
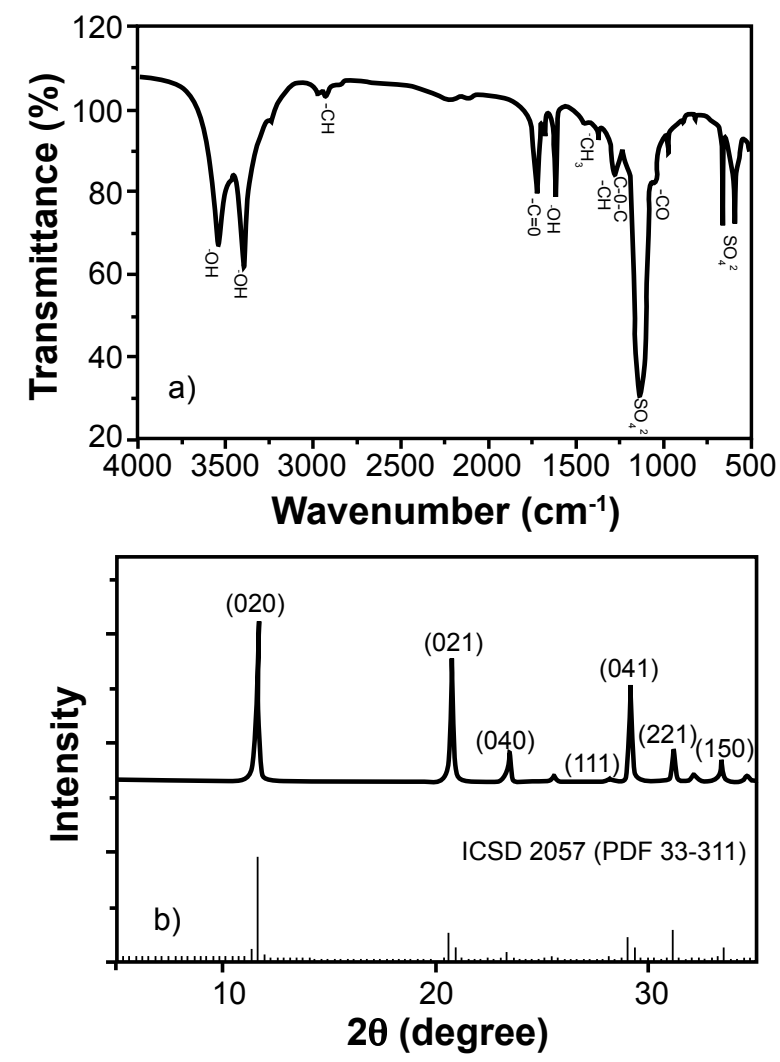

Figure 2: FTIR spectrum (a) and XRD pattern (b) of G/PHB composite.

[Figura 2: Espectro de FTIR (a) e difratograma de raios $X(b)$ do compósito G/PHB.] 
for the dihydrate gypsum at 625,672 and $1120 \mathrm{~cm}^{-1}$ for the antisymmetric stretching of $\mathrm{SO}_{4}{ }^{2-}$ groups, and $\mathrm{H}-\mathrm{O}-\mathrm{H}$ flexural vibrations at $1620,1680,3245$ and $3491 \mathrm{~cm}^{-1}$ referring to the hydration water [12], as well as the groups that characterize the PHB at $1055 \mathrm{~cm}^{-1}$ for the symmetrical stretching of C-O group, $1235 \mathrm{~cm}^{-1}$ asymmetrical stretching of C-O-C, also vibrations at $1289 \mathrm{~cm}^{-1}$ for $-\mathrm{CH}, 1381$ and $1467 \mathrm{~cm}^{-1}$ for $-\mathrm{CH}_{3}, 1726 \mathrm{~cm}^{-1}$ for $\mathrm{C}=\mathrm{O}$ and $2934 \mathrm{~cm}^{-1}$ for the $-\mathrm{CH}$ group, being in agreement with the peaks described in [13]. Based on the identification of these bands, the presence of the polymer in the composite was corroborated. The diffraction analysis of the sample did not show peaks related to PHB, which can be explained by the amorphous condition of the material, because even though PHB has a high level of crystallinity [14] its peaks are inhibited in the presence of gypsum (ICSD 2057 PDF 33-311), which is a totally crystalline material and its peaks are therefore majority when compared to those of the polymer (Fig. 2b).

Characterization of the HA/PHB composite: Fig. 3 shows the SEM micrographs of the samples after 8 and $16 \mathrm{~h}$ reaction times, the beginning of the conversion of gypsum crystals into hydroxyapatite. With $8 \mathrm{~h}$ of reaction, the presence of a material with different morphology of the gypsum crystals was observed, indicating the formation of a new phase (Fig. $3 a)$. With $16 \mathrm{~h}$ of experiment, it was possible to visualize the complete alteration of the shape of the crystals (Fig. $3 b)$. The SEM micrograph of the sample obtained at $24 \mathrm{~h}$ of reaction (Fig. 4a) confirmed the surge of particles with a new geometry that did no longer blend with the sharp form of the gypsum crystals. It was possible to observe nearly circular shapes with homogeneous distribution. The chemical composition of the formed material was analyzed by EDS (Fig. 4b), where it was possible to ascertain the presence of phosphorus, an element that is characteristic of hydroxyapatite to the detriment of sulfur present in gypsum. From the morphology of the samples resulting from the 36 $\mathrm{h}$ test (Fig. 4c), the persistence of circular shapes could be ascertained, which were connected by very thin thread-like structures. Moreover, it was possible to observe in EDS spectrum (Fig. 4d) the high peak intensities of oxygen, calcium and phosphorus, an element that is characteristic of hydroxyapatite. Besides, considering the subsequent FTIR and XRD analyses, it was concluded that the images
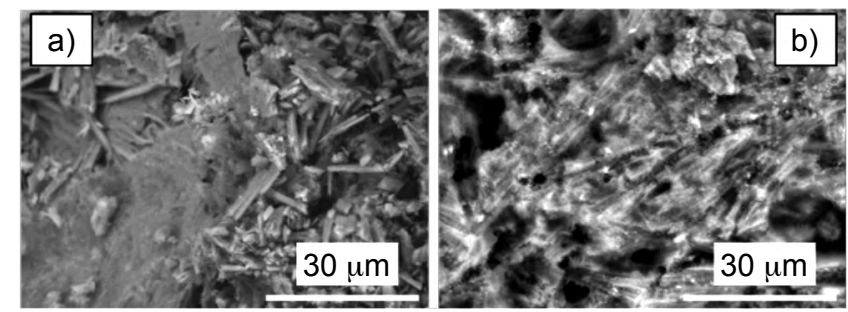

Figure 3: SEM micrographs of fractured surfaces of G/PHB composite showing the morphology during the conversion: a) 8 $\mathrm{h}$; and b) $16 \mathrm{~h}$.

[Figura 3: Micrografias de MEV de superfícies de fratura do compósito G/PHB mostrando a morfologia durante a conversão: a) $8 \mathrm{~h}$; e b) $16 \mathrm{h.J}$
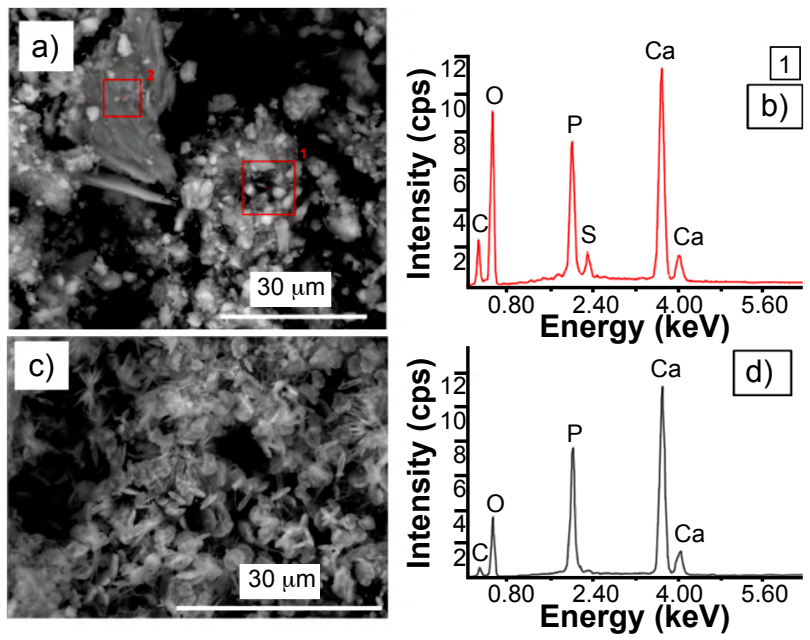

Figure 4: SEM micrographs of fractured surface of G/PHB composite showing the morphology after $24 \mathrm{~h}$ (a) and $36 \mathrm{~h} \mathrm{(c)}$ conversion and respective EDS spectrum (b,d).

[Figura 4: Micrografias de MEV de superfície de fratura do compósito G/PHB mostrando a morfologia após 24 h (a) e 36 h (c) de conversão e respectivo espectro de $\operatorname{EDS}(b, d)$.]

characterized the morphology of the HA/PHB composite.

The infrared analysis was carried out to know the new functional groups formed from the phosphorus identified through the EDS of the samples. By overlaying the graphs resulting from different test times in comparison to the absorption of the composite before the test (Fig. 5), it was observed that the band at $458 \mathrm{~cm}^{-1}$ related to the $\mathrm{SO}_{4}^{2-}$ group symmetric bend [12] disappeared already during the first $8 \mathrm{~h}$ of testing. Furthermore, it was possible to verify a dislocation of the more intense absorption band, characteristic of gypsum at $1140 \mathrm{~cm}^{-1}$, antisymmetric stretching of $\mathrm{SO}_{4}{ }^{2-}$ group [12], which appeared with reduced intensity in relation to the formation of the band at $1036 \mathrm{~cm}^{-1}$ that identified asymmetrical stretching of the $\mathrm{PO}_{4}^{3-}$ group belonging to the chemical structure of hydroxyapatite [15]. It was also possible to ascertain the decrease of the bands at $1620,3230,3406,3552 \mathrm{~cm}^{-1}$ referring to $\mathrm{H}-\mathrm{O}-\mathrm{H}$ flexural vibrations [12] that confirmed the disappearing of the hydration water present in the gypsum structure, confirming the change in the material structure. Bands at $1406 \mathrm{~cm}^{-1}$ were identified for all tests, indicating the presence of symmetrical stretching of $\mathrm{CO}_{3}{ }^{2-}$ groups [15]. This absorption reaffirmed the formation of hydroxyapatite, since the carbonate is formed due to the carbon dioxide in the atmosphere, which normally forms over the reaction. This ion easily substitutes the $\mathrm{OH}^{-}$ions that are part of the chemical structure of pure hydroxyapatite, while the $\mathrm{CO}_{3}^{2-}$ ions characterize the biological hydroxyapatite, or rather, the inorganic phase of bone [16]. Some groups related to PHB also appeared at $1285 \mathrm{~cm}^{-1}$ for symmetrical angular deformation of $\mathrm{CH}_{3}$ and $1740 \mathrm{~cm}^{-1}$ for axial deformations of carbonyl $\mathrm{C}=\mathrm{O}$ [13]. However, these were discrete in the graphs of 8 and $24 \mathrm{~h}$, showing an unaltered permanence after the reaction. Table I summarizes the presence of the characteristic functional groups of each material as a function of the conversion 
reaction time, where all groups were observed during the evolution of the experiment ( 8 to $24 \mathrm{~h}$ ) and the presence of only the assigned groups of the HA and PHB with $36 \mathrm{~h}$ of experiment.

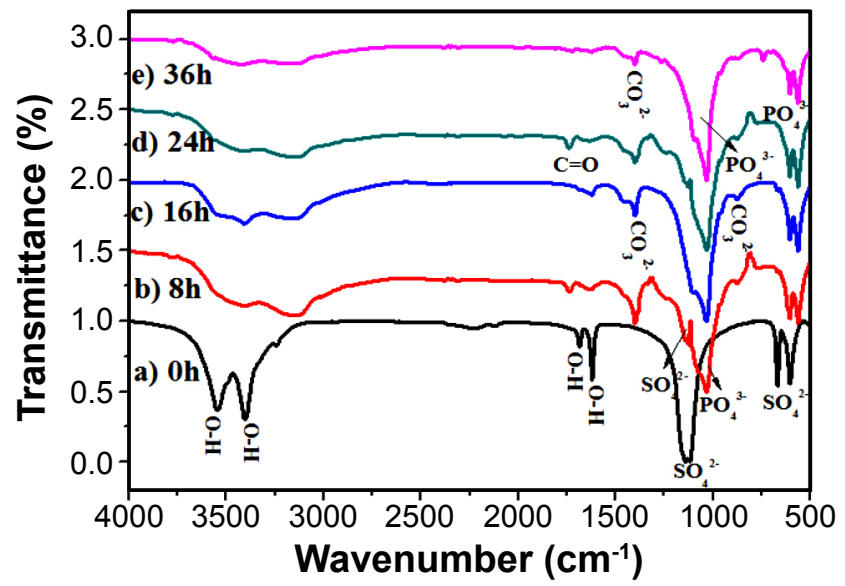

Figure 5: FTIR spectra of the G/PHB composite at different test times: a) $0 \mathrm{~h}$; b) $8 \mathrm{~h}$; c) $16 \mathrm{~h}$; d) $24 \mathrm{~h}$; and e) $36 \mathrm{~h}$.

[Figura 5: Espectros de FTIR do compósito G/PHB em diferentes tempos de teste: a) $0 \mathrm{~h}$; b) $8 \mathrm{~h}$; c) $16 \mathrm{~h}$;d) $24 \mathrm{~h}$; e e) $36 \mathrm{~h}$.]

Table I - Presence of the functional groups of gypsum (G), hydroxyapatite (HA) and polyhydroxybutyrate (PHB) as a function of conversion time.

[Tabela I - Presença dos grupos funcionais do gesso $(G)$, hidroxiapatita (HA) e poli-hidroxibutirato (PHB) em função do tempo de conversão.]

\begin{tabular}{ccccc}
\hline $\begin{array}{c}\text { Reaction } \\
\text { time (h) }\end{array}$ & \multicolumn{4}{c}{ Characteristic functional group } \\
\hline & $\mathrm{SO}_{4}^{2-}$ & $\mathrm{PO}_{4}^{3-}$ & $\mathrm{CO}_{3}^{2-}$ & $\mathrm{C}=\mathrm{O}$ \\
& $(\mathrm{G})$ & $(\mathrm{HA})$ & $(\mathrm{HA})$ & $(\mathrm{PHB})$ \\
0 & $\mathrm{X}$ & - & - & - \\
8 & $\mathrm{X}$ & $\mathrm{X}$ & $\mathrm{X}$ & $\mathrm{X}$ \\
16 & - & $\mathrm{X}$ & $\mathrm{X}$ & $\mathrm{X}$ \\
24 & $\mathrm{X}$ & $\mathrm{X}$ & $\mathrm{X}$ & $\mathrm{X}$ \\
36 & - & $\mathrm{X}$ & $\mathrm{X}$ & $\mathrm{X}$ \\
\hline
\end{tabular}

The X-ray diffraction patterns of the samples confirmed the presence of hydroxyapatite at all reaction times (Fig. 6). At $8 \mathrm{~h}$ of testing, it was observed that the material showed peaks characteristic of hydroxyapatite in the range of $30^{\circ}$ to $35^{\circ}$, but it was also verified that the more intense peaks of gypsum $\left(11.6^{\circ}, 20.7^{\circ}, 29.2^{\circ}, 31.2^{\circ}\right)$ were still prevailing in the material. After $16 \mathrm{~h}$ reaction time, it was possible to identify the phases of hydroxyapatite, calcium phosphate $\left(\mathrm{CaHPO}_{4}, \mathrm{DCPA}\right)$, as well as gypsum and PHB, coexisting in the same sample, demonstrating that the material at that moment did not have a well-defined structure, or rather, it was undergoing a transformation process. From $24 \mathrm{~h}$ experiment time (Fig. 6d), there was a better distinction between the peaks related to the hydroxyapatite phase, which was the major phase in comparison to gypsum. However, there were still some persisting peaks that characterize the DCPA phase, normally formed during the hydroxyapatite synthesis due to $\mathrm{pH}$ variations during the process. This fact is explained by the obtainment of by-products from the Ca-P system [17]. During the test at $36 \mathrm{~h}$, the reduction of the DCPA peaks was noteworthy, although a single peak related to gypsum persisted in the HA/PHB composite samples, notwithstanding the observation that the majority phase was hydroxyapatite, besides the characteristic peaks of PHB that were not altered during the conversion process.

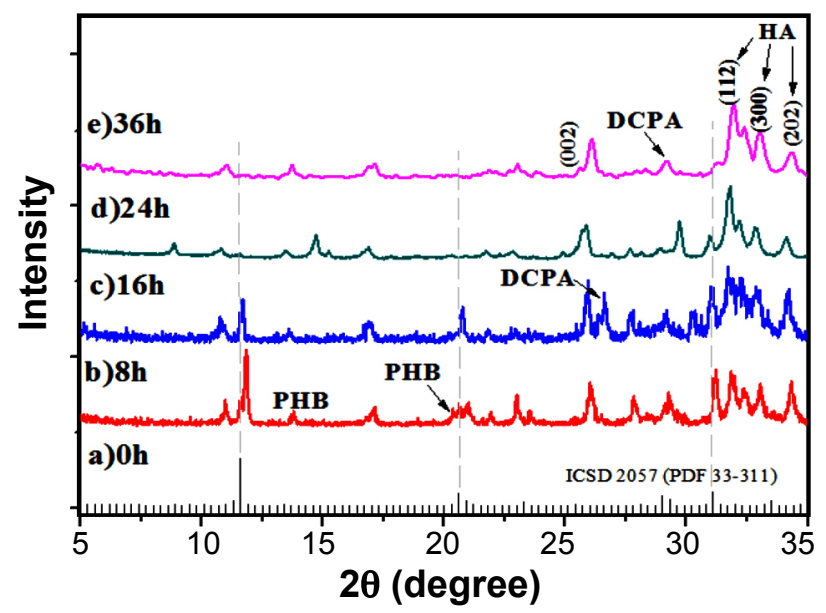

Figure 6: XRD patterns of the G/PHB composite at different test times: a) 0 h, ICSD 2057 (PDF 33-311) of gypsum; b) 8 h; c) 16 h; d) $24 \mathrm{~h}$; and e) $36 \mathrm{~h}$ (PHB, HA and DCPA denote polyhydroxybutyrate, hydroxyapatite and calcium phosphate, respectively.)

[Figura 6: Difratogramas de raios $X$ do compósito $G / P H B$ em diferentes tempos de teste: a) 0 h, ICSD 2057 (PDF 33-311) do gesso; b) $8 \mathrm{~h}$; c) $16 \mathrm{~h}$; d) $24 \mathrm{~h}$; e e) $36 \mathrm{~h}$ (PHB, HA e DCPA significam poli-hidroxibutirato, hidroxiapatita e fosfato de cálcio, respectivamente).]

It was possible to observe based on different employed techniques, that the morphology of the gypsum crystals was totally modified, without any trace of them identified during the SEM of the samples from $24 \mathrm{~h}$ reaction time. During the infrared analyses, only the functional groups related to hydroxyapatite were ascertained, evidencing the total disappearance of the gypsum hydration water. However, the XRD analyses indicated gypsum traces still present in the samples.

Conversion of $G / P H B$ composite into $H A / P H B$ : the comprehension of the occurrence of the transformation of the G/PHB composite into HA/PHB can be followed by the Eq. A:

$10 \mathrm{CaSO}_{4} \cdot 2 \mathrm{H}_{2} \mathrm{O}+6\left(\mathrm{NH}_{4}\right)_{2} \mathrm{HPO}_{4}+8 \mathrm{NH}_{4} \mathrm{OH} \rightarrow$
$\mathrm{Ca}_{10}\left(\mathrm{PO}_{4}\right)_{6}(\mathrm{OH})_{2}+10\left(\mathrm{NH}_{4}\right)_{2} \mathrm{SO}_{4}+8 \mathrm{H}_{2} \mathrm{O}$

When observing Eq. A, it can be corroborated that the $\mathrm{pH}$ control by ammonium hydroxide solution $\left(6.0 \mathrm{~mol} . \mathrm{L}^{-1}\right)$ was necessary, since, according to the diagram of the phosphate phases, it can be verified that the formation of hydroxyapatite occurs at $\mathrm{pH}$ above 6 [17], while the reaction of conversion 
of the G/PHB composite happens with a release of sulfate ions originating in the gypsum, which promote the formation of sulfuric acid $\left(\mathrm{H}_{2} \mathrm{SO}_{4}\right)$ that decreases the $\mathrm{pH}$ of the reaction medium. Therefore, the formation of hydroxyapatite occurs through the equilibrium of the reaction by addition of ammonium hydroxide solution $\left(6.0 \mathrm{~mol} . \mathrm{L}^{-1}\right)$, which promotes the neutralization of the acid and generates as a product ammonium sulfate. Another decisive factor for the formation of the biomaterial is the thermodynamic stability of the species. The standard free energy of gypsum is $-429.63 \mathrm{~kJ} \mathrm{~mol}^{-1}[18]$ and for hydroxyapatite this energy corresponds to $-12590.50 \mathrm{~kJ} \cdot \mathrm{mol}^{-1}$ [19]. Comparing the values regarding Gibbs energy, it can be concluded that the thermodynamic stability of hydroxyapatite is much higher than the gypsum, and this condition favors the reaction that seeks equilibrium through the formation of more stable species. The solubility product (Kps) also presents a positive aspect for this conversion, since the reaction is ascertained by the diffusion of ions existing in the solution, and the dissolution of these ions depends on the Kps of the involved species. In the present case, the Kps of gypsum is much higher than the one of hydroxyapatite, corresponding to $1.38 \times 10^{-4}[18]$ and $3.37 \times 10^{-58}$ at $25^{\circ} \mathrm{C}$ [16], respectively. These values suggest a greater solubility of gypsum when compared to hydroxyapatite, which explains once more the occurrence of this transformation.

\section{CONCLUSIONS}

In agreement with the employed technique and the characterization of the material, it was possible to obtain a hydroxyapatite/polyhydroxybutyrate composite from a gypsum/polyhydroxybutyrate block. The process allowed an initial molding of the block. It was ascertained that the reaction time of $36 \mathrm{~h}$ at $100{ }^{\circ} \mathrm{C}$ achieved the best results. The presence of polyhydroxybutyrate in the composite did not provide any apparent interference in the transformation, since its crystalline phases remained unaltered after the test. The biomaterial that was developed in the present work unites the biodegradability and bioactivity of the polymer to carbonated hydroxyapatite, similar to bone tissue. By this, it was possible to transform low-cost gypsum into a raw material with a higher added value.

\section{REFERENCES}

[1] A.A. Barbosa, A.V. Ferraz, G.A. Santos, Cerâmica 60 (2014) 501.

[2] D.B. Jorgensen, in "Industrial minerals and rocks", $6^{\text {th }}$ ed., Soc. Min. Metal. Expl., Colorado (1994) 571.

[3] C.A.M. Baltar, F.F. Bastos, A.B. Luz, in "Rochas e minerais industriais", CETEM (2005) 449.

[4] L.L. Hench, J. Am. Ceram. Soc. 74, 7 (1991) 1487.

[5] Chemistry Aldrich, Manual de produtos químicos, S. Paulo (2009-2010).

[6] A.A. Barbosa, A.V. Ferraz, A.C. Dantas, N.C. Olivier, Mater. Res. 17, suppl.1 (2014) 39.

[7] K.G. Marra, J.W. Szem, P.N. Kumta, P.A. Dimilla, L.E. Weiss, J. Biomed. Mater. Res. 47 (1999) 324.

[8] E.Y. Kawachi, C.A. Bertran, R.R. Reis, Quím. Nova 23, 4 (2000) 518.

[9] C.S.K. Reddy, R. Ghai, Rashmi, V.C. Kalia, Bioresour. Technol. 87 (2003) 137.

[10] G.A. dos Santos, A.A. Barbosa, L.M. de Oliveira, A.V. Ferraz, N.C. Olivier, W. Acchar, A.C.S. Dantas, Cerâmica 63, 368 (2017) 557.

[11] NBR 12128, "Gesso para construção civil: determinação das propriedades físicas da pasta", ABNT, Rio Janeiro (1991).

[12] K.M.Q. Luci, J.L. Ienczak, M. Schmidt, K. Zanfonato, M.I. Rodrigues, W. Schmidell, G.F. Aragão, Quim. Nova 38 (2015) 214.

[13] E. Knitlle, W. Phillips, Q. Williams, Phys. Chem. Miner. 28 (2001) 630.

[14] L. Avérous, C. Fringant, L. Moro, J. Polym. 42 (2001) 6565.

[15] S.V. Oliveira, S.N. Cavalcante, G.P. Rabello, E.M. Araújo, M.V.L. Fook, in VI Congr. Nac. Eng. Mec., Campina Grande (2010).

[16] J.C. Elliott, R.M. Wilson, S.E.P. Dowker, Adv. X-Ray Anal. 45 (2002) 172.

[17] E.C.S. Rigo, S.A. Gehrke, M. Carbonari, Dent. Press Period. Imp. 1, 3 (2007) 39.

[18] R.M. Silva, M. Giulietti, in "Argilominerais para o Brasil", F.R.F. Fernandes, A.B. da Luz, Z.C. Castilhos (Eds.), CETEM/MCT, Rio Janeiro (2010) 125.

[19] L.A. Iglesia, Est. Geol. 65, 2 (2009) 109.

(Rec. 19/11/2018, Rev. 23/01/2019, Ac. 04/02/2019) 